(C) 2018 by J.J. Sokołowska, K. Zalegowski. This is an open access article distributed under

the Creative Commons Attribution-NonCommercial-NoDerivs license (http://creativecommons.org/licenses/by-nc-nd/3.0/)

\title{
ULTRASONIC QUALITY ASSESSMENT OF POLYMER-CEMENT CONCRETE WITH \\ PET WASTE AS THE AGgREGATE
}

\section{J. J. SOKOLOWSKA ${ }^{1}$, K. ZALEGOWSKI ${ }^{2}$}

\begin{abstract}
Elaborating composites containing waste materials requires study of basic mechanical properties and assessment of their structure quality. The subject of investigation was PPC concrete where aggregate was substituted with PET remaining after beverages bottles grinding. Substitution was done up to $25 \%$ (by volume). Waste material was fractioned and applied in various granulations. The main goal was to indicate the influence of such modification on the composite mechanical properties and to examine composite structure quality at macro level. Since PET and quartz differ greatly in density, to perform such examination it was possible to apply the nondestructive ultrasonic method, one of the most common NDT techniques used in material science and industry. The paper presents the effects of substitution of quartz with PET on ultrasonic wave propagation in PCC. The ultrasonic test results (measurements of wave velocity) compared with results of destructive tests (flexural and compressive strength) showed great correlation.
\end{abstract}

Keywords: PCC, polymer-cement concrete, NDT, non-destructive quality control, ultrasonic method, PET, waste aggregate

\section{INTRODUCTION}

Polymer-cement concretes (PCC) appear as useful materials especially in the repair-systems applications or in the situations where improved water tightness, chemical resistance or flexural strength are required [1]. Since the polyethylene terephthalate (PET) presents great resistance to chemically aggressive media and elasticity [2], it can be considered to be a valuable filler for PCC composites. Moreover, introducing PET into PCC in the form of grinded or shredded particles of wastes changes the composite into pro-ecological and sustainable material. Efforts have been already made to apply PET waste to ordinary concrete, but due to the low adhesion of the cement paste to the

\footnotetext{
${ }^{1}$ Ph.D., Warsaw University of Technology, Faculty of Civil Engineering, Al. Armii Ludowej 16, 00-637 Warsaw, Poland, e-mail: j.sokolowska@il.pw.edu.pl

${ }^{2}$ M.Sc., University of Technology, Faculty of Civil Engineering, Al. Armii Ludowej 16, 00-637 Warsaw, Poland, e-mail: k.zalegowski@il.pw.edu.pl
} 
plastic, the results were not satisfactory [3], however some studies showed acceptable decrease in strength when PET was applied into lightweight concrete [4]. The introduction of a plastic filler into the polymer-cement mix seemed to be more justified. The polymer binder has better adhesion to the smooth surface of the solid polymer particles. Authors have already tested polymer-cement concretes containing grinded high density polypropylene (HDPP) wastes, and the results turned out to be promising [5]. That previous study enabled authors to determine the reasonable range of substitution of mineral aggregate with PET waste material in composites presented in this paper. The applied modification of aggregate resulted in producing polymer-cement concretes with mechanical properties not worse than non-modified ones.

The aim of the paper, however, was not to assess the mechanical strength but the quality of these composites using a non-destructive ultrasonic method, assuming the determination of velocity of ultrasonic wave passing through the tested composite. Since filler type and size are considered to be important factors affecting the ultrasonic wave propagation [6], [7], in this paper the effect of substitution of quartz aggregate with PET waste (introduced in various contents and granulation) on ultrasonic wave propagation in PCC is discussed.

\section{TESTED MATERIALS AND METHODOLOGY}

The authors decided to use the ultrasonic method to determine the quality of polymer-cement composites with PET waste filler, because substituting quartz sand with grinded PET, i.e. material of different density and morphology of the grains was expected to significantly affect the propagation of ultrasonic wave in the composite. And since the ultrasonic method has proved to be useful for assessment of the quality of ordinary concretes [8][9] as well as polymer concretes [6], [7] authors decided to apply it also in case of polymer-cement concretes. Decisively, in the framework of presented research, three types of composites were tested: polymer-cement mortar (without PET waste filler), polymer-cement concretes (created by introducing thicker aggregate, i.e. particles of waste PET filler larger than $4 \mathrm{~mm}$, into the polymer-cement mortar) and - as an additional reference composite - the standard cement mortar. The division of polymer-cement composites into concrete and mortar due to the size of the aggregate is not always used, so all such composites analyzed in the paper are labelled PCC. Each composite contained standard sand (meeting requirements of standard PN-EN 196-1), Portland fly ash cement of high early strength, class 42.5 (CEM II/A-V 42.5 R) and characterized by water-cement ratio of 0.5 . Polymer-cement composites contained also polymer 
binder (styrene-acrylic copolymer) in amount of $6 \%$ of cement mass. The mineral aggregate in polymer-cement composites was substituted by PET waste in contents of $10 \%, 20 \%$ and $25 \%$ by volume. As for the granulation of the waste material: some of the composites contained not fractioned PET filler (supplied straight from the grinder) - particles of size up to $8 \mathrm{~mm}$ (fractions $0-4 \mathrm{~mm}$ and 4-8 $\mathrm{mm}$ in proportion $1: 2$ by weight, total loose bulk density of $244 \mathrm{~kg} / \mathrm{m}^{3}$ ) while the other contained plastics of particular fraction (0-4 $\mathrm{mm}$ or 4-8 $\mathrm{mm}$ of loose bulk density respectively 314 and 207 $\mathrm{kg} / \mathrm{m}^{3}$ ) extracted from the waste. The issue of need of fractioning the waste material was important from the economical point of view, since any additional treatment of the waste increases its cost. The compositions of tested composites (expressed in \% of total volume of composite) are presented in Fig. 1.
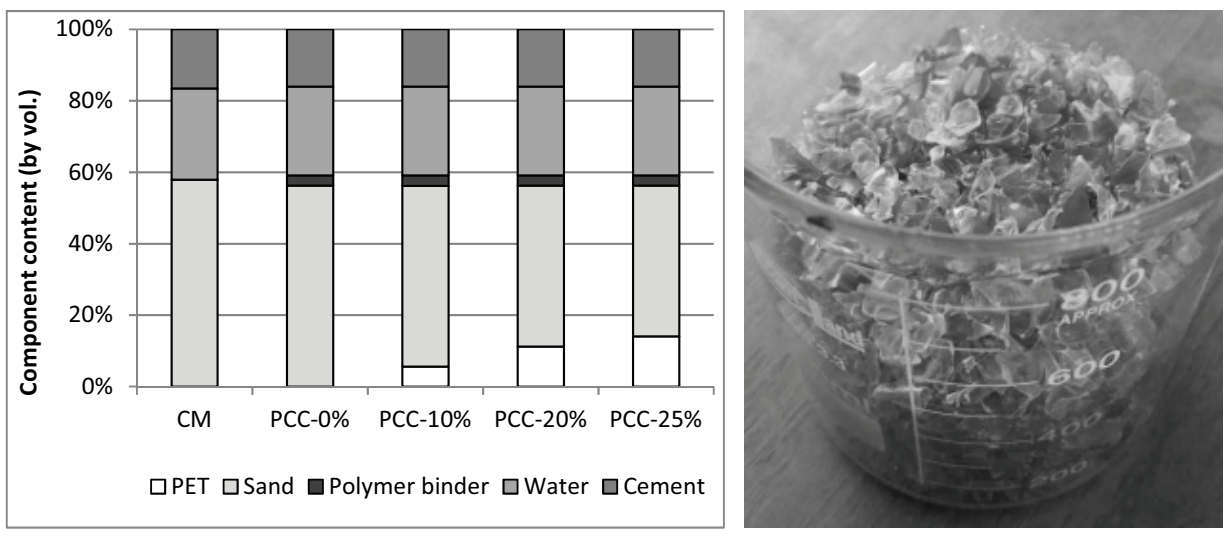

Fig. 1. Left: Volumetric composition of tested composites: $\mathrm{CM}$ - cement mortar, PCC - polymer-cement composite (where $0 \%, 10 \%, 20 \%$ and $25 \%$ means the content of PET in the total aggregate volume), right: the finest (fraction 0-4 mm) PET blend

For each composite the set of technical properties was determined as following: apparent density, flexural strength and compressive strength (see next paragraph, Table 1). The properties were determined after 28 days of curing in mixed conditions including 7 days in water and 21 days in laboratory conditions (only the standard mortar was cured in water for 28 days, as required in standard PN-EN 196-1). Flexural strength was tested on standard specimens in the shape of beams of size 40 $\mathrm{mm} \times 40 \mathrm{~mm} \times 160 \mathrm{~mm}$ in the three-point bending test, compressive strength was tested on the halves of the beams remaining after bending (apparent density was tested on the same specimens before destructive tests) according to the methods described in standard PN-EN 196-1. 
The ultrasonic tests were conducted on the same specimens (also before destructive tests), i.e. on standard specimens in the shape of beams of size $40 \mathrm{~mm} \times 40 \mathrm{~mm} \times 160 \mathrm{~mm}$. The ultrasonic testing was done using the direct method [6] and was conducted using a digital ultrasonic flaw detector EPOCH4 Parametrics. To ensure good contact between the tested specimens and heads of signal emitter and receiver, the specialized coupling agent was used. The tests were done using a piezoelectric transducer of frequency of $100 \mathrm{kHz}$. The recorded data included the times of ultrasonic waves passing through the composite of known thickness (so called transit times), which were the basis to calculate ultrasonic waves velocity. Knowing the wave velocity for different composites it was possible to determine the influence of PET waste content on the propagation of ultrasonic wave as well as the relations between composite technical properties and ultrasonic wave velocity.

\section{ULTRASONIC TESTS RESULTS AND DISCUSSION}

The test included the determination of transit time (in $\mu \mathrm{s}$ ) of ultrasonic wave passing through the specimens of cement mortar (CM) and polymer-cement concretes (PCC) of known dimensions (measured with precision of $0.01 \mathrm{~mm}$ ) and the calculation of the wave velocity (in $\mathrm{m} / \mathrm{s}$ ) according to the procedure described in standard PN-EN 12504-4. The results (average values) are given in Table 1.

Table 1. Density (d), flexural strength $\left(f_{b}\right)$, compressive strength $\left(f_{c}\right)$ and ultrasonic wave velocity $\left(c_{p}\right)$ of cement mortar (CM) and polymer-cement concretes (PCC) - average values

\begin{tabular}{|c|c|c|c|c|c|c|}
\hline No & Composite type & PET/A[\%] & $\mathrm{d}\left[\mathrm{kg} / \mathrm{m}^{3}\right]$ & $\mathrm{f}_{\mathrm{b}}[\mathrm{MPa}]$ & $\mathrm{f}_{\mathrm{c}}[\mathrm{MPa}]$ & $\begin{array}{c}\text { Ultrasonic wave } \\
\text { velocity, } \mathrm{c}_{\mathrm{p}}[\mathrm{m} / \mathrm{s}]\end{array}$ \\
\hline 1 & CM & 0 & 2279 & 8.02 & 57.13 & 2755.17 \\
\hline 2 & PCC-0 & 0 & 1965 & 5.66 & 30.13 & 2572.77 \\
\hline 3 & PCC-10 $(0-4 \mathrm{~mm})^{*}$ & 10 & 1897 & 4.44 & 27.19 & 2435.54 \\
\hline 4 & PCC-20 $(0-4 \mathrm{~mm}) *$ & 20 & 1896 & 5.12 & 29.92 & 2437.42 \\
\hline 5 & PCC-25 $(0-4 \mathrm{~mm})^{*}$ & 25 & 1900 & 5.20 & 27.63 & 2292.27 \\
\hline 6 & PCC-25 $(4-8 \mathrm{~mm})^{*}$ & 25 & 1774 & 4.29 & 19.30 & 2333.91 \\
\hline 7 & PCC-25 $(0-8 \mathrm{~mm}) *$ & 25 & 1891 & 4.46 & 24.92 & 2261.01 \\
\hline
\end{tabular}

*) The ranges in brackets describe the fraction of used PET filler, CM and PCC-0 contained only standard sand (fraction 0-2 mm) 
Measurements of ultrasonic wave velocity of various composites showed first of all, that adding polymer as co-binder to cement mix causes changes in propagation of ultrasonic wave. In case of polymer-cement mortar ultrasonic wave velocity was $6.6 \%$ lower than it was in case of cement mortar. The second finding was that the more PET waste was introduced into PCC instead of quartz aggregate, the lower was the ultrasonic wave velocity. It was possible to describe this relation by second degree polynomial function (very well fit to empiric data: coefficient of correlation, $\mathrm{R}=0.95$, coefficient of determination, $\mathrm{R}^{2}=0.89$ ) - Figure $2 \mathrm{a}$.

Above findings seem to be reasonable since density of used styrene-acrylic copolymer was 1050 $\mathrm{kg} / \mathrm{m}^{3}$ and density of used polyethylene terephthalate was $1380 \mathrm{~kg} / \mathrm{m}^{3}$ (i.e. much less in comparison to quartz density $2650 \mathrm{~kg} / \mathrm{m}^{3}$ ) which affected strongly the apparent density of composites consisting of these organic materials (see Table 1). Also in case of apparent density it was possible to find the mathematical relation between the density of the composites (including the standard mortar) and the ultrasonic wave velocity (again very well fit to empiric data: $R=0.97, R^{2}=0.94$ ) - Figure $2 b$.

a)

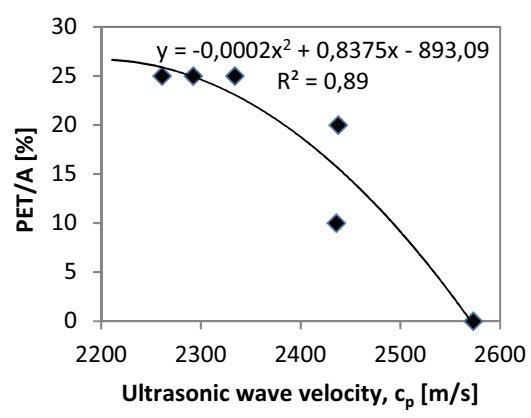

b)

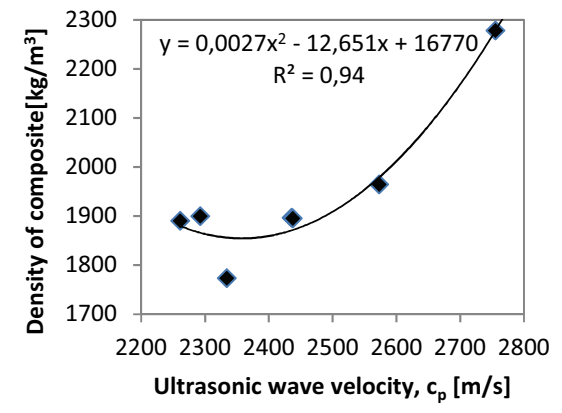

Fig. 2. Ultrasonic wave velocity ( $\left.c_{\mathrm{p}}\right)$ vs. a) content of PET waste in aggregate (PET/A, vol.\%) in PCC, b) apparent density of the composites with/without PET

Destructive tests of mechanical strength did not showed any strong effect of introducing PET on flexural strength nor compressive strength of PCC composites. Though in general PCC turned out to be weaker than the standard mortar (which is well known effect of introducing polymer binder into cement mix), the comparison of results obtained among PCC composites showed that only the ones containing coarse aggregate (i.e. PET of size bigger than $4 \mathrm{~mm}$ ) showed the decrease in strength. The worst flexural strength and compressive strength (respectively: 4.29 MPa and 19.30 MPa) showed PCC containing $25 \%$ of PET of granulation $4-8 \mathrm{~mm}$, the second worst - the PCC containing $25 \%$ of PET of granulation 0-8 $\mathrm{mm}$, which was not fractioned waste. Based on these findings it can be 
concluded, that fractioning the grinded PET waste, especially use of fine fractions $(0-4 \mathrm{~mm})$, is required to avoid the decrease in mechanical strength of polymer-cement composites like the ones described in the paper.

Yet, again it was possible to describe the relation between the mechanical properties of composites (including PCC and the standard mortar) and the ultrasonic wave velocity by second degree polynomial regression functions (very well fit to empiric data: coefficients of correlation and determination not lower than $\mathrm{R}=0.96, \mathrm{R}^{2}=0.92$ ) - Figure 3. The relations showed that the stronger (in terms of flexural strength and compressive strength) was the composite, the higher was the ultrasonic wave velocity. Authors decided to use the second degree polynomial despite the fact that in case of $f_{c}-c_{p}$ relation most standards and guidelines recommend linear and exponential type of regression function [6][10] as using it polynomial gave much better correlation with empiric data.

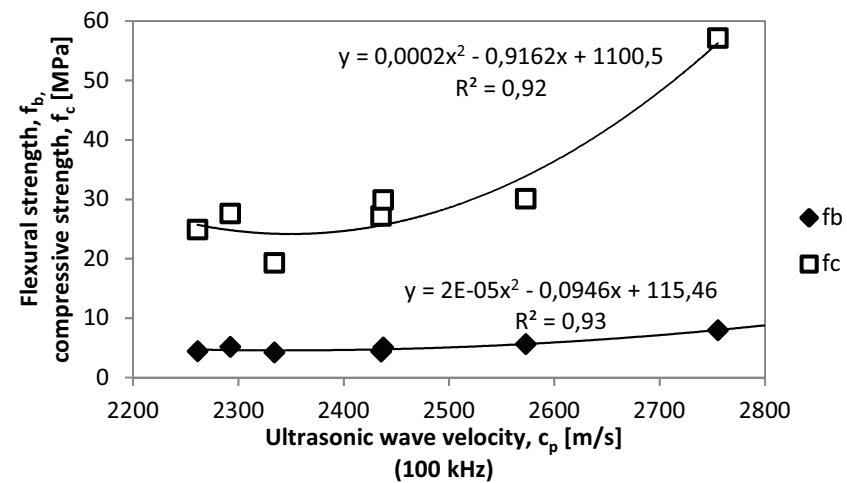

Fig. 3. Ultrasonic wave velocity $\left(c_{p}\right)$ vs. flexural strength $\left(f_{b}\right) /$ compressive strength $\left(f_{c}\right)$ of the PCC with/without PET waste and standard mortar - the regression functions (in form of second degree polynomials) describing ultrasonic wave velocity in function of aforementioned technical properties were very well fit to empiric data

To examine homogeneity of composite containing various contents of PET material in comparison to PCC without PET, as well as to check how the granulation of the waste influences the heterogeneity, the testing was actually done on 6 specimens and the standard deviation (SD) and coefficient of variance $(\mathrm{CV})$ were determined. The obtained results showed that the tested material turned out to be homogeneous despite the use of relatively high content of waste material (up to $25 \%$ of aggregate) of large particles size (up to $8 \mathrm{~mm}$ ). Table 2 presents the subsequent measurements of transit times and calculated ultrasonic wave velocities as well as above mentioned statistical characteristics obtained 
in case of chosen polymer-cement composites: a non-modified composite (without PET) and two composites containing the highest used content of waste in aggregate $(\mathrm{PET} / \mathrm{A}=25 \%)-$ one containing non-fractioned PET (particles of size 0-8 $\mathrm{mm}$ ) and one with only coarse fraction of PET (4-8 $\mathrm{mm})$ - considered to be the worst filler that caused the biggest decrease in mechanical strength of PCC composites. Standard deviation and coefficient of variance in case of PCC with PET were slightly higher than in case of pure polymer-cement composite but still the values were very low. Still, one can see that when the composite contained non-fractioned waste (derived straight from the grinder) not only the ultrasonic wave velocity was lower $\left(c_{\mathrm{p}, 0-8}=2261.01 \mathrm{~m} / \mathrm{s}\right)$ but standard deviation $\left(\mathrm{S}_{\mathrm{D} 0-8}=85.29 \mathrm{~m} / \mathrm{s}\right)$ and coefficient of variance $\left(\mathrm{C}_{\mathrm{V} 0-8}=3,77 \%\right)$ were higher than in case of composites with fractioned waste (respectively: $\mathrm{c}_{\mathrm{p}, 4-8}=2333.91 \mathrm{~m} / \mathrm{s}, \mathrm{S}_{\mathrm{D} 4-8}=62.91 \mathrm{~m} / \mathrm{s}, \mathrm{C}_{\mathrm{V} 4-8}=2.70 \%$ ). This confirms that fractioning the PET waste enable us to obtain more homogeneous composites.

Table 2. Average ultrasonic wave velocity $\left(\mathrm{c}_{\mathrm{p}}\right)$, standard deviation $(\mathrm{SD})$ and coefficient of variance $(\mathrm{CV})$ of chosen PCC with/without PET waste in aggregate (A)

\begin{tabular}{|c|c|c|c|c|c|c|c|c|}
\hline \multirow{2}{*}{ No } & \multirow{2}{*}{ Composite type } & \multirow{2}{*}{$\mathrm{PET} / \mathrm{A}[\%]$} & \multirow{2}{*}{$\mathrm{b}[\mathrm{mm}]$} & \multirow{2}{*}{$\mathrm{t}[\mu \mathrm{s}]$} & \multicolumn{4}{|c|}{ Characteristics of ultrasonic wave velocity } \\
\hline & & & & & $\mathrm{c}_{\mathrm{p}}[\mathrm{m} / \mathrm{s}]$ & $\begin{array}{c}\text { Average } \\
{[\mathrm{m} / \mathrm{s}]}\end{array}$ & $\mathrm{SD}[\mathrm{m} / \mathrm{s}]$ & $\mathrm{CV}[\%]$ \\
\hline 1.1 & \multirow{6}{*}{ PCC-0 } & \multirow{6}{*}{0} & 39.85 & 15.5 & 2570.97 & \multirow{6}{*}{2572.77} & \multirow{6}{*}{41.39} & \multirow{6}{*}{1.61} \\
\hline 1.2 & & & 40.00 & 15.4 & 2597.40 & & & \\
\hline 1.3 & & & 40.37 & 16.0 & 2523.13 & & & \\
\hline 1.4 & & & 40.23 & 15.9 & 2530.19 & & & \\
\hline 1.5 & & & 40.28 & 15.3 & 2632.68 & & & \\
\hline 1.6 & & & 40.80 & 15.8 & 2582.28 & & & \\
\hline 2.1 & \multirow{6}{*}{$\begin{array}{c}\text { PCC-25 } \\
(0-8 \mathrm{~mm})\end{array}$} & \multirow{6}{*}{25} & 40.21 & 18.6 & 2161,83 & \multirow{6}{*}{2261.01} & \multirow{6}{*}{85.29} & \multirow{6}{*}{3.77} \\
\hline 2.2 & & & 39.39 & 17.7 & 2225.42 & & & \\
\hline 2.3 & & & 40.35 & 17.3 & 2332.37 & & & \\
\hline 2.4 & & & 39.74 & 18.3 & 2171.58 & & & \\
\hline 2.5 & & & 39.70 & 17.1 & 2321.64 & & & \\
\hline 2.6 & & & 40.24 & 17.1 & 2353.22 & & & \\
\hline 3.1 & \multirow{6}{*}{$\begin{array}{c}\text { PCC-25 } \\
(4-8 \mathrm{~mm})\end{array}$} & \multirow{6}{*}{25} & 39.88 & 17.8 & 2240.45 & \multirow{6}{*}{2333.91} & \multirow{6}{*}{62.91} & \multirow{6}{*}{2.70} \\
\hline 3.2 & & & 40.30 & 17.1 & 2356.73 & & & \\
\hline 3.3 & & & 40.03 & 16.8 & 2382.74 & & & \\
\hline 3.4 & & & 39.93 & 17.1 & 2335.09 & & & \\
\hline 3.5 & & & 39.96 & 16.6 & 2407.23 & & & \\
\hline 3.6 & & & 40.15 & 17.6 & 2281.25 & & & \\
\hline
\end{tabular}




\section{CONCLUSIONS}

On the basis of presented research, the following conclusions concerning ultrasonic assessment of polymer-cement concrete with PET waste filler used as the aggregate may be formulated:

1) The tested material, i.e. polymer-cement composite in which mineral aggregate was partially (up to $25 \%$ by volume) substituted with PET waste, despite the use of relatively large PET particles, turned out to be homogeneous.

2) Both, destructive and non-destructive tests confirmed the necessity of fractioning of grinded PET and use of fine fractions. Adding particles of PET larger than $4 \mathrm{~mm}$ (filler corresponding with coarse aggregate) to mix of PCC resulted in deterioration of mechanical strength of composites, while adding the same amount of PET of fraction 0-4 $\mathrm{mm}$ did not resulted in decrease.

3) The obtained results showed correlation of ultrasonic wave velocity values with content of PET waste in aggregate of tested composites. The following tendencies were noted: the more PET filler was introduced into PCC instead of quartz aggregate, the lower was the ultrasonic wave velocity (which was followed by conclusion that the higher was the composite apparent density, the higher was also the ultrasonic wave velocity).

4) The obtained results showed correlation of ultrasonic wave velocity values with the flexural strength and compressive strength of tested composites. The general tendency was that the stronger was the composite, the higher was the ultrasonic wave velocity.

Thus, it was showed that ultrasonic testing method can be useful for assessment of quality of polymercement composites containing PET filler. Further testing, performed on composites of more diverse compositions (e.g. various water-cement ratio, increased PET waste content, etc.) would allow to refine the regression function so that one could treat them as tools for predicting the composites technical properties without the necessity of performing destructive tests.

\section{ACKNOWLEDGMENTS}

Part of the presented results was obtained in cooperation with Jakub Kurlak and Daniel Bińkowski in the framework of their B.Sc. theses realized at WUT under supervision of J.J. Sokołowska. 


\section{REFERENCES}

1. Czarnecki L., Sokołowska J. Optimization of polymer-cement coating composition using material model, Key Engineering Materials, 466, 2011, 191-199;

2. Iroh J.O., Poly(ethylene terephthalate) in James E. Mark: Polymer Data Handbook. Oxford University Press, 1999, s. 558-560;

3. Wiliński D., Łukowki P., Rokicki G., Application of fibres from recycled PET bottles for concrete reinforcements, Journal of Building Chemistry, 1, 2016, 1-9;

4. Dipta I.A., Rahat M., Alam A., Islam M.J., A Study on Green Lightweight Concrete using Recycled PolyEthylene Terephthalate (PET) as Coarse Aggregate, ICERIE Conference, SUST, 2017, Sylhet;

5. Sokołowska J.J., Piotrowski T., Garbacz A., Kowalik P., Effect of introducing recycled polymer aggregate on the properties of C-PC composites, Advanced Materials Research, 687, 2013, 520-526;

6. Garbacz A., Garboczi E.J., Ultrasonic evaluation methods applicable to polymer concrete composites, NIST Report nr NISTIR 6975, National Institute of Standards and Technology, Gaithersburg, 2003;

7. Garbacz A., Sokołowska J., Lutomirski A., Courard L., Fly ash polymer concrete quality assessment using ultrasonic method, Proc. of 7th Asian Symposium on Polymers in Concrete - ASPIC 2012, Istanbul, Turkey, 2012, 573-580;

8. Brunarski L., Runklewicz L., Basis for and examples of the use of nondestructive methods in the investigation of concrete structures [in Polish], Institute of Construction Engineering, Warszawa, 1983;

9. Schabowcz K., Neural networks in the NDT identification of the strength of concrete, Archives of Civil Engineering, 51, 3, 2005, 371-382;

10. Runkiewicz L., Załęgowski K., Piotrowski T., Garbacz A., Application of ultrasonic method to estimation of mechanical properties of shielding concretes (Zastosowanie metody ultradźwiękowej do oceny właściwości mechanicznych betonów osłonowych), Przegląd Spawalnictwa, 87, 12, 2015, 17-20. 


\section{LIST OF FIGURES AND TABLES:}

Fig. 1. Volumetric composition of tested composites: $\mathrm{CM}$ - cement mortar, $\mathrm{PCC}$ - polymer-cement composite (where $0 \%, 10 \%, 20 \%$ and $25 \%$ means the content of PET in the total aggregate volume), right: the finest (fraction 0-4 mm) PET blend

Rys. 1. Skład objętościowy badanych kompozytów: CM - zaprawa cementowa, PCC - kompozyt polimerowocementowy (gdzie $0 \%, 10 \%, 20 \%$ i 25\% oznacza zawartość PET w całkowitej objętości kruszywa), prawa: najdrobniejsza (frakcja 0-4 mm) mieszanka PET.

Fig. 2. Ultrasonic wave velocity $\left(c_{p}\right)$ vs. a) content of PET waste in aggregate (PET/A, \% by volume) in PCC, b) apparent density of the composites with/without PET

Rys. 2. Prędkość fali ultradźwiękowej ( $c_{\mathrm{p}}$ ) w stosunku do a) zawartości odpadów PET w kruszywie (PET/A, \% objętości) w PCC, b) gęstości pozornej kompozytów z/bez PET.

Fig. 3. Ultrasonic wave velocity $\left(c_{p}\right)$ vs. flexural strength $\left(f_{b}\right) /$ compressive strength $\left(f_{c}\right)$ of the PCC with/without PET waste and standard mortar - the regression functions (in form of second degree polynomials) describing ultrasonic wave velocity in function of aforementioned technical properties were very well fit to empiric data

Rys. 3. Prędkość fali ultradźwiękowej $\left(\mathrm{c}_{\mathrm{p}}\right)$ w stosunku do wytrzymałości na zginanie $\left(\mathrm{f}_{\mathrm{b}}\right)$ /wytrzymałości na ściskanie $\left(f_{c}\right)$ PCC bez/z odpadami PET i standardową zaprawą - funkcje regresji (w postaci wielomianów drugiego stopnia), opisujące prędkość fali ultradźwiękowej w funkcji wyżej wspomnianych właściwości technicznych, były bardzo dobrze dopasowane do danych empirycznych.

Table 1. Density $(d)$, flexural strength $\left(f_{b}\right)$, compressive strength $\left(f_{c}\right)$ and ultrasonic wave velocity $\left(c_{p}\right)$ of cement mortar (CM) and polymer-cement concretes (PCC) - average values

Tabela 1. Gęstość (d), wytrzymałość na zginanie (f $\left.f_{b}\right)$, wytrzymałość na ściskanie (f $\left.f_{c}\right)$ i prędkość fali ultradźwiękowej $\left(\mathrm{c}_{\mathrm{p}}\right)$ zaprawy cementowej $(\mathrm{CM})$ i betonów polimerowo-cementowych (PCC) - średnie wartości.

Table 2. Average ultrasonic wave velocity $\left(\mathrm{c}_{\mathrm{p}}\right)$, standard deviation $(\mathrm{SD})$ and coefficient of variance $(\mathrm{CV})$ of chosen PCC with/without PET waste in aggregate (A)

Tabela 2. Średnia prędkość fali ultradźwiękowej $\left(\mathrm{c}_{\mathrm{p}}\right)$, standardowe odchylenie (SD) i współczynnik wariancji (CV) wybranych PCC z/bez odpadów PET w kruszywie (A). 


\section{ZASTOSOWANIE METODY ULTRADŹWIĘKOWEJ DO OCENY JAKOŚCI BETONU POLIMEROWO-CEMENTOWEGO ZAWIERAJĄEGO ODPADY PET}

Słowa kluczowe: PCC, beton polimerowo-cementowy, NDT, nieniszcząca ocena jakości, metoda ultradźwiękowa, PET, kruszywo odpadowe

\section{STRESZCZENIE:}

Opracowanie nowego kompozytu zawierającego komponenty odpadowe wymaga nie tylko przeprowadzenia badań jego cech technicznych, ale też oceny jakości jego struktury. Przedmiotem badań zaprezentowanych w artykule był beton polimerowo-cementowy (PCC), w którym kruszywo częściowo (do 25\% objętości) zastąpiono odpadem ze zmielonych butelek PET. Odpad był frakcjonowany i dodawany do mieszanek w różnej zawartości i granulacji. Celem badań było określenie wpływu takiej modyfikacji na właściwości mechaniczne oraz makrostrukturę kompozytu. Z uwagi na dużą różnicę w gęstościach kwarcu i poli(tereftalan etylenu) możliwe było zastosowanie metody ultradźwiękowej - jednej z najpowszechniej stosowanych w badaniach i przemyśle metod nieniszczących (NDT). W artykule zaprezentowano efekty substytucji kwarcu odpadem PET na propagację fal ultradźwiękowych w betonie PCC. Analiza statystyczna wyników pomiarów prędkości fali oraz wartości wytrzymałości na zginanie, wytrzymałości na ściskanie i gęstości pozornej poszczególnych kompozytów wskazuje na ich bardzo silną korelację. 